BULLETIN OF THE

AMERICAN MATHEMATICAL SOCIETY

Volume 79, Number 4, July 1973

\title{
THE ANNUAL MEETING IN DALLAS
}

The seventy-ninth annual meeting of the American Mathematical Society was held at the Fairmont Hotel in Dallas, Texas, from Thursday, January 25, through Sunday, January 28, 1973. The meeting was held in conjunction with the annual meeting of the Association for Symbolic Logic, the annual meeting of the Mathematical Association of America, and a meeting of the National Council of Teachers of Mathematics. There were 3,162 registrants, including 2,314 members of the Society.

The forty-sixth Josiah Willard Gibbs Lecture was presented by Professor Jürgen K. Moser of the Courant Institute of Mathematical Sciences, New York University, on Thursday evening. The title of Professor Moser's lecture was The stability concept in dynamic systems. He was introduced by Professor Saunders Mac Lane.

Professor Michael F. Atiyah of Oxford University gave a series of four Colloquium Lectures on the subject The index of elliptic operators. The presiding officers at the four lectures were Professors Saunders Mac Lane, Isadore M. Singer, Lesley M. Sibner, and Karen K. Uhlenbeck.

By invitation of the Committee to Select Hour Speakers for Annual and Summer Meetings, there were seven invited hour addresses. The speakers and their titles were as follows: Professor William K. Allard of Princeton University, Some unsolved regularity problems in the calculus of variations; Professor Samuel Gitler of the Instituto Politécnico Nacional in Mexico City, Cohomology operations and obstructions; Professor Barbara L. Osofsky of Rutgers University, The subscript of $\aleph_{n}$, projective dimension, and the vanishing of $\lim ^{(\mathrm{n})}$; Professor Henry B. Mann of the University of Arizona, Additive group theory. A progress report; Professor Lester E. Dubins of the University of California, Berkeley, The abstract gambler's problem; Professor Michael E. Fisher of Cornell University, The hunt for singularities in statistical mechanics; Professor Nicholas M. Katz of Princeton University, Some remarks on differential equations in algebraic geometry. The following mathematicians presided at these seven lectures: Professors John E. Brothers, Mark E. Mahowald, Joseph J. Rotman, Olga Taussky Todd, Joseph L. Doob, Seymour Sherman, and Amassa C. Fauntleroy.

The second and third George David Birkhoff Prizes in Applied Mathematics were awarded on January 27 to Professor Fritz John of the Courant Institute of Mathematical Sciences and to Professor James B. Serrin of the University of Minnosota. The prize was awarded to Professor John for his outstanding work in partial differential equations, in numerical analysis, and, particularly, in nonlinear elasticity theory. This latter work has led to his study of 
quasi-isometric mappings as well as functions of bounded mean oscillation, which have had impact in other areas of analysis. Professor Serrin was awarded a prize for his fundamental contributions to the theory of nonlinear partial differential equations, especially his work on existence and regularity theory for nonlinear elliptic equations, and applications of his work to the theory of minimal surfaces in higher dimensions.

The George David Birkoff Prize in Applied Mathematics was awarded on Saturday afternoon, January 27.

On Friday evening there was a panel discussion on Graduate Education in Mathematics in the Coming Decade. This was chaired by Professor Raoul M. Bott of Harvard University. Members of the panel were Professor Peter L. Duren, University of Michigan; Mr. Robert E. Jamison, University of Washington; Professor Arthur Ogus, Princeton University; Professor Calvin C. Moore, University of California, Berkeley; and Professor Jacob T. Schwartz, New York University.

There were twelve special sessions of selected twenty-minute papers. Professor Joanne Elliott of Rutgers University arranged a special session on Probability and Related Topics in Analysis; the speakers were Simeon M. Berman, Donald L. Burkholder, Adriano M. Garsia, Ronald K. Getoor, Richard F. Gundy, P. Warwick Millar, Stanley A. Sawyer, Martin L. Silverstein, Daniel W. Stroock, and Willian A. Veech. Professor John W. Gray of the University of Illinois and Professor Saunders Mac Lane of the University of Chicago arranged a special session on Category Theory; the speakers were David Finkel, Peter J. Freyd, Horst Herrlich, Miguel L. Laplaza, Michael J. Liddell, Pierre J. Malraison, Jr., Christopher J. Mulvey, David C. Newell, Janet Fisher-Palmquist, and Joseph L. Taylor. Professor Mary W. Gray of American University arranged a special session on Ring Theory; the speakers were David Eisenbud, E. Graham Evans, Jr., Kent R. Fuller, Robert Gordon, Aron V. Jategoankar, Dana May Latch, Lawrence S. Levy, M. Susan Montgomery, Louis H. Rowen, Judith D. Sally, Robert L. Snider, Wolmer V. Vasconcelos, Robert B. Warfield, Jr., and Roger A. Wiegand. Professor Paul R. Halmos of Indiana University arranged a special session on Compact Perturbations of Operators; the speakers were Lewis A. Coburn, James A. Deddens, Peter A. Fillmore, Douglas N. Clark, Carl M. Pearcy, and Peter M. Rosenthal. Professor Erik Hemmingsen of Syracuse University arranged a special session on Maps of Manifolds on Manifolds; the speakers were James W. Cannon, Philip T. Church, George K. Francis, R. Christopher Lacher, Morris L. Marx, Louis F. McAuley, Daniel R. McMillan, Jr., Thomas M. Price, William L. Reddy, Carl B. Shepardson, and David C. Wilson. Professor Peter A. Loeb of 
the University of Illinois arranged a special session on Nonstandard Analysis; the speakers were Allen R. Bernstein, Donald J. Brown, C. Ward Henson III, Reuben Hersh, Peter J. Kelemen, Peter A. Loeb, Wilhelmus A. J. Luxemburg, Lawrence C. Moore, Jr., Rohit J. Parikh, Abraham Robinson, K. D. Stroyan, Frank A. Wattenberg, and Volker B. Weispfenning. Professor Gian-Carlo Rota of Massachusetts Institute of Technology arranged a special session on Combinatorial Theory; the speakers were Edward A. Bender, Kenneth P. Bogart, Richard A. Brualdi, Thomas H. Brylawski, Thomas A. Dowling, Steve Fisk, Michael L. Fredman, Ladnor D. Geissinger, Jay R. Goldman, William H. Graves, Curtis Green, Lawrence H. Harper, Douglas Harris, Douglas G. Kelly, Thomas L. Magnanti, Robert J. McEliece, Vera S. Pless, Neil Robertson, Bruce L. Rothschild, Richard P. Stanley, William T. Trotter, Jr., Neil L. White, Stanley G. Williamson, and Richard M. Wilson. Professor Mary Ellen Rudin of the University of Wisconsin arranged a special session on General Topology; the speakers were Richard A. Alò, Richard D. Anderson, W. Wistar Comfort, Charles L. Hagopian, Robert W. Heath, James E. Keesling, David J. Lutzer, Jun-iti Nagata, George M. Read, Jack W. Rogers, Jr., Mary Ellen Rudin (replacing Roger W. Hansell), Jack Segal, Anne K. Steiner, Robert M. Stephenson, Jr., Franklin D. Tall, and Howard H. Wicke. Professor Lowell I. Schoenfeld of the State University of New York at Buffalo arranged a special session on Number Theory; the speakers were George E. Andrews, A. O. L. Atkin, Bruce C. Berndt, Itshak Borosh, Leonard Carlitz, Mohindar S. Cheema, Harvey Cohn, P. T. D. A. Elliott, Janos Galambos, Richard K. Guy, Richard B. Lakein, R. Sherman Lehman, Carlos J. Moreno, Morris Newman, Harald G. Niederreiter, and Karl K. Norton. Professor Michio Suzuki and John H. Walter arranged a special session on Finite Groups; the speakers were Michael Aschbacher, Robert H. Gilman, George Glauberman, David M. Goldschmidt, Marshall Hall, Jr., Koichiro Harada, Morton E. Harris, Donald G. Higman, William M. Kantor, Michael E. O'Nan, Arunas Rudvalis, Leonard L. Scott, Jr., Gary M. Seitz, Ernest E. Shult, Louis Solomon, Ronald M. Solomon, and David Wales. Professor Mitchell H. Taibleson arranged a special session on Harmonic Analysis over Local Fields; the speakers were Jia-arng Chao, Stephen S. Gelbart, John A. Gosselin, Charles F. Gulizia, Edwin Hewitt, Richard A. Hunt, Cornelis W. Onneweer, Keith L. Phillips, Paul J. Sally, Jr., Mitchell H. Taibleson, and Daniel Waterman. Professor John Todd of the California Institute of Technology arranged a special session on Numerical Mathematics; the speakers were Edward K. Blum, James W. Daniel, Walter Gautschi, J. Wallace Givens, Jr., William B. Jones, Herbert B. Keller, Isaac J. Schoenberg, Lawrence F. Shampine, Richard S. Varga, 
David M. Young Jr., and Hans J. Zassenhaus.

Four informal sessions were scheduled and held. The subjects and moderators of these sessions were as follows: Ring Theory, Professor E. Graham Evans, Jr., of the University of Illinois; Complex Analysis, Professor Ralph P. Boas, Jr., of Northwestern University; Ordinary and Functional Differential Equations, Professor Jack K. Hale of Brown University; Number Theory, Professor John L. Selfridge of Northern Illinois University and Professor Paul Erdös of the Hungarian Academy of Sciences.

There were 55 sessions of contributed ten-minute papers. Of the 578 ten-minute papers listed in the program of the meeting, only 540 were actually presented in person. The following 65 mathematicians served as presiding officers for these sessions: William K. Allard, Joel H. Anderson, Howard Anton, James W. Armstrong, Raymond Balbes, Karl F. Barth, Lida K. Barrett, Felice D. Bateman, C. B. Bell, Harold E. Benzinger, Bruce C. Berndt, David G. Bourgin, John W. Brown, R. Creighton Buck, Robert F. Craggs, Lokenath Debnath, James A. Deddens, Ralph E. DeMarr, Larry L. Dornhoff, Patricia J. Eberlein, Ralph J. Faudree, Jr., George K. Francis, Michael B. Freeman, George Gasper, Jr., Frank L. Gilfeather, Samuel Gitler, J. Wallace Givens, Jr., Deborah T. Haimo, Lester L. Helms, Wlodzimierz Holsztynski, Richard A. Hunt, Carl G. Jockusch, Jr., Gene A. Klaasen, Dana May Latch, Leon R. McCulloch, Michael Menn, Joseph B. Miles, Josephine Mitchell, J. Donald Monk, Cathleen S. Morawetz, Carlos J. Moreno, Howard A. Osborn, Janet Fisher-Palmquist, Anthony L. Peressini, Hala O. Pflugfelder, Vera S. Pless, M. Rajagapolan, Lee A. Rubel, Judith D. Sally, Subhash C. Saxena, Donald R. Sherbert, Ralph E. Showalter, Martha K. Smith, Robert L. Snider, B. Salzberg Stark, Ellen R. Stone, Walter C. Strodt, Leopoldo V. Toralballa, J. Jerry Uhl, Jr., Samuel S. Wagstaff, Jr., John E. Wetzel, Mary Fanett Wheeler, Sylvia M. Wiegand, John E. Wolfe, and Bertram Yood.

The Council met on January 24, at 2:05 P.M. in the Gold Room of the Fairmont Hotel. President Mac Lane was in the chair.

The Secretary reported the election of Paul Halmos and Dorothy $\mathbf{M}$. Stone to the Executive Committee and the election of Richard R. Goldberg to the Editorial Committee of the Proceedings.

The Council endorsed the establishment of quality graduate programs in the mathematical sciences at Traditionally Black Institutions and agreed to join with the Mathematical Association of America and the National Association of Mathematicians in appointing a committee which can advise and assist in various ways, including securing financial support and suitable faculty. 
The Council approved a reviewing charge of $\$ 25$ for each article published in Society journals. The charge is to be added to publication charges, beginning with articles accepted in July 1973, and is to be collected at the same time and in the same way that publication charges are currently collected.

The Council passed a resolution urging the National Science Foundation to reinstitute its postdoctoral fellowship programs.

The Council adopted the following resolution as the sense of the Council as then assembled:

We have the highest admiration for the achievements of Soviet mathematicians, whom we regard as friends and honored colleagues. For this reason, among others, we are gravely concerned about the restrictions being imposed on some of them in regard to foreign travel and emigration and about the methods now being used in the enforcement of these regulations.

We believe that in the common interest of our two countries, and in the interest of the world scientific community, scholars should be free to make foreign visits. It is evident that many Soviet mathematicians do not have this freedom, and this imposes hardships on us as well as on them.

The situation with regard to emigration is more disturbing still. We recognize that in the Soviet Union university students pay no fees and, in fact, receive stipends. Reasonable men may argue that this justifies, in principle, a required period of service at the end of formal education, or some form of payment in lieu of service, sometimes taking the form of an emigration tax. But the present policies and practices of your government are not covered or justified by this principle.

In some cases an emigration tax is imposed which exceeds, by a large factor, the annual salary of the person who must pay it, and insufficient account is taken for years of service. Furthermore, the loss of pension rights is not considered at all when the tax is imposed. Moreover, even for those able and willing to pay the tax, there is no guarantee of the right of emigration. In fact, there have been dismaying reports of people being dismissed from their jobs simply because they have indicated a desire to emigrate. In the cases that we have heard about, these policies have been applied to Jews wishing to emigrate to Israel. Thus it appears in practice that higher education and scientific achievement, in themselves, may lead to a reduction in the ability to exercise basic human rights. 
We recognize that discussions of issues like these are commonly used as weapons of international propaganda. However, this is remote from the intent of our present communication. We believe that the world community of scholars generally agrees in opposing the policies and practices that we have just been discussing, and we wish to lend all the support that we can to those scholars in the Soviet Union who share our conception of the way in which the scholarly world should live and work.

[The Secretary notes that President Mac Lane transmitted the above resolution to Academician Mstislav V. Keldysh under a covering letter dated February 2, 1973 and that the latter had received it.]

The Council invited Professor Jerome Keisler to be a Colloquium Lecturer at the Annual Meeting of 1975 in Washington, D.C.

The Council approved recommendations of the Committee on Women in Mathematics to maintain a roster of women with Ph.D.'s in mathematics and to cooperate with the Mathematical Association of America to investigate the status of women not in the Ph.D. track.

The Council resolved to establish a one year program of American Mathematical Society research fellowships, to be awarded strictly on the basis of mathematical merit and to be supported by a combination of appropriated Society funds and solicited funds, with 1974-1975 as the year of tenure. In so doing, the Council noted that the Trustees had agreed to appropriate a minimum of $\$ 9000$, or a larger amount equal to half the funds raised from other sources, but not more than $\$ 20,000$.

The Council passed the following resolution:

The Council of the American Mathematical Society takes note of the following resolution, passed at the Business Meeting of the Society in January of 1972.

(1) The American Mathematical Society will work actively for equal opportunities for women in the following areas:

(a) employment at all levels: this will include the search for and recruitment of qualified women,

(b) advancement and tenure in academic positions,

(c) admissions to graduate schools,

(d) graduate and postdoctoral fellowships and assistantships,

(e) membership on advisory boards and panels and

(2) the Society will include more women on

(a) Society programs and panels, including invited speakers and section chairmen,

(b) Society committees and governing boards. 
The Council endorses the above resolution. Resolutions resembling it in some ways have sometimes been interpreted as calling for policies under which various agencies would attempt to promote the careers of women even at the price of lowering the professional standards which would otherwise be set. We do not believe that the resolution passed by the Business Meeting has any such meaning or intent, and we do not favor any such policies. We believe, however, that without any sacrifice of professional standards, academic institutions can and should make reasonable accommodations to the special conditions of women's lives. In particular, we believe that maternity leaves should be regarded as a matter of course. In institutions where tenure and promotion decisions must made in a certain number of years, the reckoning should be made on the basis of full-time-equivalent years rather than calendar years. In assessing the quality of a person's research, a single standard should be applied, but the quantity of research should be judged with due regard to whatever years have been spent on a part-time professional basis.

During the meeting there was an intermission for dinner. The Council adjourned at $11: 40$ P.M.

The Business Meeting was convened by President Mac Lane at 3:00 P.M. on January 27,1973 in the Regency Ballroom of the Fairmont Hotel.

The Secretary reported on some of the Council actions detailed above.

Dr. Diane Laison introduced a procedural resolution that three resolutions be placed on the agenda of the Business Meeting at the Annual Meeting of 1974 in San Francisco. The text of the three resolutions is as follows:

1. In cases of alleged discrimination against mathematicians in matters of hiring, promotion, or tenure, for reasons of racial, sex, or political bias, the American Mathematical Society shall pay legal expenses for the complainant, in those cases where the complainant, in the opinion of the Council, has made out a prima facie case of such discrimination.

2. The American Mathematical Society declares itself in favor of the massive transfer of funds from the federal military budget to the support of education, including higher education, and calls upon the Council and staff to engage the Society in lobbying and publicity efforts directed to this end.

3. The American Mathematical Society views with alarm the present practice of increasing class sizes and teaching loads, and other measures designed to save money by decreasing faculties at the expense of educational quality. The Council and staff of the Society are called upon to seek avenues for inducing colleges and universities to reverse this unhealthy trend. 
A resolution to separate the question into three procedural resolutions failed. The procedural resolution then passed.

It was noted that the resolutions would be considered by the Council, by the Executive Committee of the Council, and by an ad hoc committee and that comments from members could be addressed to the Secretary. Some advantages and disadvantages of a ballot by mail were discussed.

Professor Anatole Beck introduced the following resolution:

The business meeting urges the Council and staff of the Society to be more solicitous of the financial resources of the membership in the choice of meeting sites, and requests that there not be a repetition of the enormously expensive meeting now finishing.

After discussion of pertinent matters, the resolution was passed.

The meeting was adjourned at 4:05 P.M.

Bethlehem, Pennsylvania

EVerett Pitcher Secretary

Paul T. Bateman

URBANA, ILLINOIS Associate Secretary

\section{THE APRIL MEETING IN STANFORD}

The seven hundred second meeting of the American Mathematical Society was held at Stanford University, Stanford, California, on Saturday, April 14, 1973. There were 115 registrants including 95 members of the Society.

By invitation of the Committee to Select Hour Speakers for Far Western Sectional Meetings, there were two invited addresses. Professor Theodore W. Gamelin of the University of California, Los Angeles, lectured on The algebra of bounded analytic functions. He was introduced by Professor William G. Badé. Professor Robert M. Blumenthal of the University of Washington addressed the Society on Stopping time constructions. He was introduced by Professor K. Bruce Erickson.

Professor David Gilbarg organized two Special Sessions on Partial Differential Equations consisting of thirty-minute talks. The speakers were Michael G. Crandall, Paul C. Fife, C. Denson Hill, Mario Miranda, Keith Miller and L. M. Simon.

There were six sessions of contributed ten-minute papers. They were chaired by Afton H. Cayford, Herman Chernoff, Moses E. Cohen, Karel De Leeuw, Myron Krom, and Stuart A. Seligson. 